\title{
Article
}

\section{The future of the professions: how technology will transform the work of human experts (Book Review)}

\author{
Taylor, Amanda M L \\ Available at http://clok.uclan.ac.uk/14402/ \\ Taylor, Amanda M L (2016) The future of the professions: how technology will \\ transform the work of human experts (Book Review). Social Work Education: \\ The International Journal .
}

It is advisable to refer to the publisher's version if you intend to cite from the work. http://dx.doi.org/10.1080/02615479.2016.1165474

For more information about UCLan's research in this area go to http://www.uclan.ac.uk/researchgroups/ and search for < name of research Group>.

For information about Research generally at UCLan please go to http://www.uclan.ac.uk/research/

All outputs in CLoK are protected by Intellectual Property Rights law, including Copyright law. Copyright, IPR and Moral Rights for the works on this site are retained by the individual authors and/or other copyright owners. Terms and conditions for use of this material are defined in the policies page.

\section{CLoK}

Central Lancashire online Knowledge www.clok.uclan.ac.uk

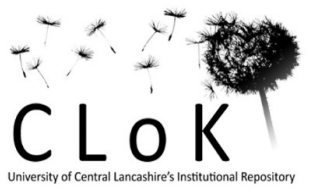


The Future of the Professions: How Technology Will Transform the Work of Human Experts, Richard, E. Susskind \& Daniel Susskind, Oxford, Open University Press, 2015, pp. 368, ISBN 9780198713395 (hbk), £14.99

Susskind and Susskind (2015) present a thought-provoking and pointed analysis of the professions within the context of technological change in 'The Future of the Professions: How Technology Will Transform the Work of Human Experts'. They begin by providing an overview of the nature of the professions, and go on to outline the modifications that have occurred as a result of how users of services are accessing knowledge as a result of technological advancements. The overall discussion is strengthened by a considered objectivity that confronts the exclusivity which once set the professions apart from the rest of society.

Even though the authors do not make direct reference to social work they capture the essence of how technology has influenced the modernisation of practices within professions such as law, medicine, education and even the clergy. They emphasise the ways in which traditionally recognisable characteristics of the professions are under threat and urge the professions to begin to reconceptualise their practices in this emerging digital world or risk the danger of being excluded from having a role in shaping the inevitable changes ahead. Furthermore, they indicate a possible demise of the professions in their current form, describing a seismic shift away from the 'print-based industrial society' where the 
professional is expert to a 'technology-based Internet society' in which expert needs to think through how they 'share [their] expertise in society' (p.2)

Susskind and Susskind's cite numerous examples of how technology has changed not only professional practices but also where these practices have taken place, and this gives their arguments a convincing focus and context. No longer are the professions geographically constrained: this is a truly global phenomenon.

For example, they recount the surgeons in the United States who removed the gall bladder of a women $6000 \mathrm{~km}$ away in France without even setting foot on French soil (p.50); the robot pharmacist that processed 2 million prescriptions with only one error during a period of one year, whilst the US population of human pharmacists drug errors amount to approximately 37million each year (p.49); the fact that in education 'the sage on the stage' is gradually being remoulded into 'the guide on the side' (p.60); that more students have signed up to online courses in one year than have attended university in its 377 years of its existence (p.1) and that even the clergy are moving online, with one app designed to help people prepare for confession (p.64). Considerable changes to professional routines, customs and procedures, each illustrating the fact the 'increasingly capable systems' (p.152) are impacting, and not always negatively, on not only what constitutes a profession but also how a profession goes about its business. 
This book raises many questions for social work. For instance, has the profession considered the implications of the tasks that have been, or potentially could, be replaced by technologies? Or, how is social work education preparing students for practice in the digital age? Furthermore, are practitioners being provided with continuing professional development that attends to digital knowledge or literacy gaps? If the answer to any of the above is 'no' then perhaps it is time to delve into the pages of this text. What is found might just prompt, with a degree of urgency, a re-evaluation of social work's response to 'need' in the digital age.

Social work as a profession values transparency and openness and has a deep appreciation for the right to privacy (Fook \& Pease, 2016). Recent failures in relation to online behaviours and decision making in England (Stevenson, 2014 and Bingham, 2016) indicate the need to work through how students and practitioners are both being prepared for, and are practising in the technological age. Susskind and Susskind's book suggests that we need to rethink the whole notion of 'expert' and consider how the changes in the practice landscape must be reflected in the social work curriculum and practice standards. First, the appropriateness of preand post-qualification education needs to be re-assessed; and, second in the context of the digital world, there remains an absolute need for ethical practice, underpinned by the professional code of ethics and, social work's value base. 
This book will be an edifying read for those with a hand in shaping social work education and practice. It provides an opportunity to think ahead and to avoid the potential for further issues for the profession as it embraces new technologies. Fundamentally, there is need for the profession to address, what Rafferty (2014: xi) explains as, 'a disjointedness between the energy and effort that is being expended in higher education on using technology to 'transform' the learning experience' and a necessity to take heed of the need, 'to mirror in social work skills and understanding the reality of the use of technology in the world we now live in'.

As Susskind and Susskind (2015: 307) advise, 'inaction, as well as action is a choice. If we choose to do nothing, and we decided to default to our traditional ways and discard the promise of technological change for fear, say, of rocking the boat, then this is a decision for which the later generations can hold us responsible.'

\section{References}

Bingham, J. (2016) Christian student expelled for opposing gay marriage. [online] Available at:

http://www.telegraph.co.uk/news/religion/12176380/Christian-studentexpelled-for-opposing-gay-marriage.html (Assessed 02 March 2016).

Fook, J. \& Pease, B. (Eds.) (2016) Transforming social work practice: Postmodern critical perspectives. Routledge.

Rafferty, J. (2014) Foreword. In Westwood, J. (2014) Social Media in Social Work Education. Northwich: Critical Publishing.

Stevenson, L. (2014) HCPC sanctions social worker over Facebook posts. [online] Available at: http://www.communitycare.co.uk/2014/09/10/social- 
worker-given-conditions-practice-order-disrespectful-facebook-posts/ (Accessed 01 March 2016).

\section{Amanda Taylor}

Senior Lecturer, School of Social Work

University of Central Lancashire, UK 